\title{
Synthesis and Biological Evaluation of Cytogenin Derivatives
}

\author{
Naoki Matsumoto, Takashi Nakashima, Kunio Isshiki, Hiroshi Kuboki, Shin-ichi Hirano,

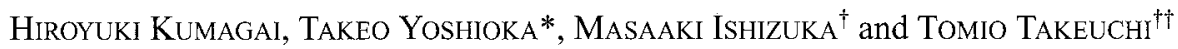 \\ Central Research Laboratories, Mercian Corp., \\ 4-9-1, Johnan, Fujisawa 251-0057, Japan \\ ${ }^{\dagger}$ Institute for Chemotherapy, M. C. R. F., \\ 18-24 Aza-Motono, Miyamoto, Numazu-shi, Shizuoka 410-0301, Japan \\ ${ }^{\dagger}$ Institute of Microbial Chemistry, \\ 3-14-23 Kamiosaki, Shinagawa-ku, Tokyo 141-0021, Japan
}

(Received for publication October 18, 2000)

To enhance the stability in vivo, new derivatives of cytogenin were synthesized, and their biological activity and stability in mice were estimated. 2-(8-Hydroxy-6-methoxy-1-oxo-1H-2benzopyran-3-yl)propionic acid (NM-3) was found to be the most stable among them. It modified collagen-induced arthritis in mice. It also showed potent anti-angiogenic activity in a mouse dorsal air sac assay.

Cytogenin 1 (Fig. 1) was first found as an immunomodulative antitumor substance produced by Streptoverticillum eurocidium ${ }^{1)}$. Later, it was found that cytogenin had an antiinflammatory activity against collagen-induced arthritic model in mice ${ }^{2,3)}$. However, cytogenin readily transformed to the less active sulfate or glucronide, or was oxidized to the 3-carboxylic acid (MC-1) in the biological assessment in mice. These metabolic conversions seemed to reduce efficacy of cytogenin. So we prepared $O$-acyl and $O$-alkyl derivatives of cytogenin to prevent glucuronide or sulfate conjugation, and the 3-side chain modified analogues to avoid oxidation. Among these derivatives, NM-3 (2a in Fig. 1) showed the best pharmacological properties. In this paper, we report the syntheses, stability in vivo, and the pharmacological activities of the cytogenin derivatives.

\section{Materials and Methods}

\section{$O$-Acyl Derivatives of Cytogenin}

As shown in Scheme 1, O-acyl derivatives 4 11 were prepared simply by acylation with acylating agent in the presence of base (method A), or by nucleophilic displacement of the chloride $\mathbf{3}$, which was easily prepared by chlorination of cytogenin with $\mathrm{PPh}_{3}-\mathrm{CCl}_{4}$, with the corresponding nucleophilic reagent (method $\mathrm{B})$.

Fig. 1. Structures of cytogenin and NM-3.<smiles>COc1cc(O)c2c(=O)oc(CO)cc2c1</smiles>

Cytogenin 1<smiles>COc1cc(O)c2c(=O)oc(C(C)C(=O)O)cc2c1</smiles>

NM-3 2a

* Corresponding: n-matsumoto@hkg.odn.ne.jp 
Scheme 1. O-Acyl derivatives of cytogenin.

\begin{tabular}{|c|c|c|c|c|c|}
\hline \multirow[b]{2}{*}{ Compound } & \multirow[b]{2}{*}{$\mathrm{R}^{1}$} & \multicolumn{2}{|c|}{ acylating reagent, base } & \multirow[b]{2}{*}{ base } & \multirow[b]{2}{*}{ yield (\%) } \\
\hline & & $R^{2}$ & acylating reagent & & \\
\hline 4 & $H$ & $A C$ & $\mathrm{Ac}_{2} \mathrm{O}(1.2 \mathrm{eq})$ & pyridine & 51 \\
\hline 5 & $A C$ & $A C$ & $\mathrm{Ac}_{2} \mathrm{O}(12 \mathrm{eq})$ & pyridine & 53 \\
\hline 6 & $\mathrm{H}$ & $\mathrm{CO}\left(\mathrm{CH}_{2}\right)_{2} \mathrm{CO}_{2} \mathrm{H}$ & succinic anhydride & none & 74 \\
\hline 7 & $\mathrm{H}$ & $\mathrm{CO}\left(\mathrm{CH}_{2}\right)_{3} \mathrm{CO}_{2} \mathrm{H}$ & glutamic anhydride & none & 77 \\
\hline 8 & $H$ & $\mathrm{COCH}_{2} \mathrm{Ph}$ & phenacyl chloride & pyridine & 74 \\
\hline
\end{tabular}

method B<smiles>[R7]Cc1cc2cc(OC)cc(O)c2c(=O)o1</smiles>

3

\begin{tabular}{cllll} 
Compound & $\mathrm{R}^{1}$ & \multicolumn{1}{c}{$\mathrm{R}^{2}$} & nucleophilic reagent & yield (\%) \\
\hline $\mathbf{9}$ & $\mathrm{H}$ & $\mathrm{COCH}(\mathrm{OH}) \mathrm{Ph}$ & DL-manderic acid & 79 \\
$\mathbf{1 0}$ & $\mathrm{H}$ & $\mathrm{COCH}\left(\mathrm{NH}_{2}\right) \mathrm{CH}\left(\mathrm{CH}_{3}\right)_{2}$ & Boc-valine & 55 \\
11 & $\mathrm{H}$ & $\mathrm{COCH}\left(\mathrm{NH}_{2}\right) \mathrm{CH}_{2}\left(\mathrm{CH}_{2}\right)_{3} \mathrm{NH}_{2}$ & $\mathrm{~N}, \mathrm{~N}$-di-Boc-lysine & 77 \\
\hline
\end{tabular}

In the method A, acylation generally occurs at the 9position first, and acylation at the 8-position was slow because of the hydrogen bond with the 1-carbonyl group. In the method B, after the nucleophilic displacement, the Boc group was deprotected by TFA, if necessary.

\section{$O$-Alkyl Derivatives of Cytogenin}

$O$-Alkyl derivatives $12,13,14$ and 16 were prepared as shown in Scheme 2. Treatment of cytogenin with excess methyl iodide and sodium hydride gave the 6,8,9-Otrimethyl derivative 12. Compound 13 was obtained after the selective demethylation of $\mathbf{1 2}$ at 8-position by boron trichrolide in dichloromethane. Treatment of cytogenin with $t$-butylbromoacetate and $\mathrm{K}_{2} \mathrm{CO}_{3}$ in dimethylformamide gave selective $O$-alkylation at the 8 -position. Removal of the $t$-butyl group by TFA gave the 8 - $O$-carboxymethyl ether 14.

On the other hand, the 9-O-carboxymethyl derivative
16 was prepared as follows. The intermediate, 8-monomethoxymethyl cytogenin $\mathbf{1 5}$, was prepared successively by methoxymethylation of 3 , nucleophilic displacement of a 9-chlorine atom with sodium formate, and hydrolysis of the formate. After alkylation of $\mathbf{1 5}$ with $t$-butylbromoacetate, the protective groups was removed, affording the 9-O-carboxymethyl ether $\mathbf{1 6}$.

\section{Oxidized Derivative of Cytogenin (MC-1)}

Oxidation of cytogenin with Jones' reagent provided the 3-carboxyisocoumarine, MC-1, in 62\% yield (Scheme 2), which was identical with one of the metabolites of cytogenin in mice.

\section{Modification of the Side Chain}

We designed the homologue of MC-1 not to be subjected to decarboxylation. The reaction of 3 with sodium cyanide in dimethylsulfoxide afforded the nitrile 17. The desired 9- 
Scheme 2. O-Alkyl derivatives of cytogenin.

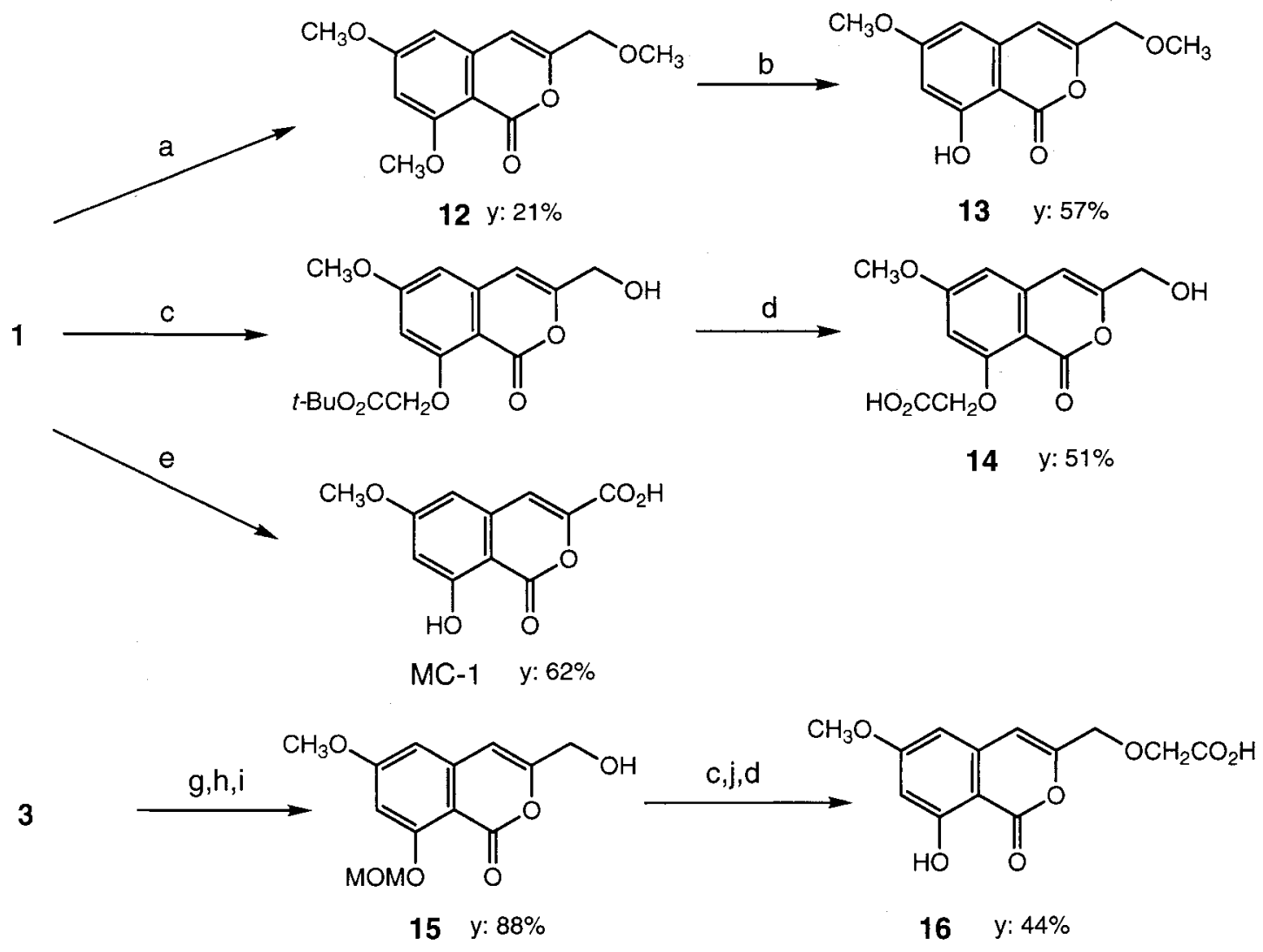

a: $\mathrm{CH}_{3} \mathrm{l}, \mathrm{NaH} / \mathrm{DMF} ; \mathrm{b}: \mathrm{BCl}_{3} / \mathrm{CH}_{2} \mathrm{Cl}_{2}$; c: $\mathrm{BrCH}_{2} \mathrm{CO}_{2} t$-Bu, $\mathrm{K}_{2} \mathrm{CO}_{3} / \mathrm{DMF} ; \mathrm{d}: \mathrm{CF}_{3} \mathrm{CO}_{2} \mathrm{H} / \mathrm{CH}_{2} \mathrm{Cl}_{2}$; e: $\mathrm{CrO}_{3}, \mathrm{H}_{2} \mathrm{SO}_{4}$; f: $\mathrm{Ph}_{3} \mathrm{P} / \mathrm{CCl}_{4} ; \mathrm{g}: \mathrm{ClCH}_{2} \mathrm{OCH}_{3}$, NaH/DMF; h: $\mathrm{HCO}_{2} \mathrm{Na} / \mathrm{DMF}$; i: $\mathrm{NaHCO}_{3} / \mathrm{CH}_{3} \mathrm{CN} ; \mathrm{j}: 1 \mathrm{M} \mathrm{HCl} / \mathrm{CH}_{3} \mathrm{CN}$

carboxy derivative 2 was obtained by heating of the nitrile 17 in a $1: 1$ mixture of concentrated hydrochloric acid and acetic acid (Scheme 3).

\section{C-Alkyl Derivative of $\mathbf{2}$}

The preparation of $C$-alkyl derivatives are shown in Scheme 3. First, the 8-hydroxyl group in $\mathbf{1 7}$ was protected as the tert-butyldimethylsilyl ether 18. Usual alkylation procedures such as sodium hydride and alkyl halide gave the dialkyl product as a main product. So we employed the two phase system of aqueous sodium hydroxide and dichloromethane in the presence of tetrabutyl ammonium bromide as a phase transfer catalyst to obtain the monoalkyl product. Even under these conditions, the reaction should be stopped generally within an hour before the dialkyl compound become a major product. Thus, mono-alkyl compounds 19a $\sim \mathbf{c}$ were prepared along with the recovery of about a half the amount of the starting material 18 .
Mono alkyl nitriles $19 \mathbf{a} \sim \mathbf{c}$ were hydrolyzed to $\mathbf{2 a}(\mathrm{NM}-3)$, $\mathbf{2 b}$ and $\mathbf{2 c}$, respectively.

Dialkyl derivatives $\mathbf{2 0 a} \sim \mathbf{c}$ were obtained by using sodium hydride and alkyl halide, concomitant with partial desilylation as a side reaction. The 9,9-dimethylnitrile $\mathbf{2 0 a}$ was hydrolyzed to give the carboxylic acid 21a in $45 \%$ yield. However, the complete hydrolysis proved more resistant on the more hindered dialkyl compounds $20 \mathrm{~b}$ and 20c under the same or even more drastic conditions, affording only the carbamoyl compounds 21 b and 21 c, respectively.

\section{Results and Discussion}

\section{Metabolite Profile}

Orally administered cytogenin was rapidly metabolized in mice and excreted in urine mainly as the 8 (or 9)-O- 
Scheme 3. Modification of the side chain.<smiles></smiles>

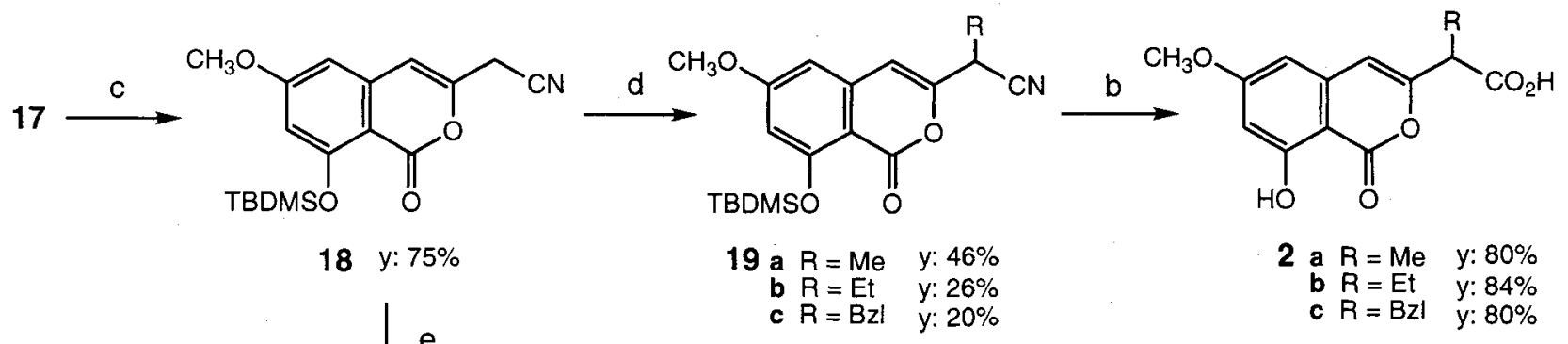

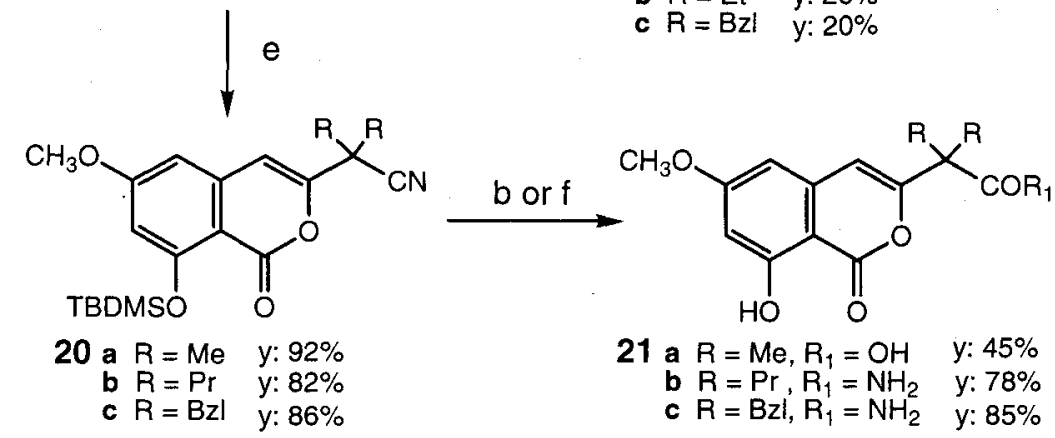

a: $\mathrm{NaCN} / \mathrm{DMSO}$; b: $\mathrm{HCl}, \mathrm{AcOH}$; c: $t$-butyldimethylchlorosilane, imidazole/DMF; $\mathrm{d}$ : $\mathrm{RX}, \mathrm{NaOH}, \mathrm{Bu}_{4} \mathrm{NBr} / \mathrm{CH}_{2} \mathrm{Cl}_{2}$; e: RX, $\mathrm{NaH} / \mathrm{THF} ; \mathrm{f:} \mathrm{H}_{2} \mathrm{SO}_{4}, \mathrm{AcOH}$

sulfonate (MCS), the 8 (or 9)-O-glucuronate (MCG) and the 3-carboxylic acid (MC-1). That was confirmed by the HPLC analysis of the metabolites before and after hydrolysis with sulfatase and/or glucuronidase. The rate of these compounds, MCS, MCG and MC-1, found in urine was: $26 \%$ (retention time $=4$ minutes), $22 \%$ ( 4.5 minutes) and $24 \%$ (18 minutes), respectively, only $7 \%$ cytogenin remained at 5.5 minutes. Another experiment showed that about $70 \%$ of cytogenin was conjugated in a plasma.

In vitro and in vivo stability are shown in Table $1 . O$-acyl derivatives $4,5,8,9$ and 10 were unstable in a plasma and deacylated to cytogenin. Although the $O$-acyl derivatives having a carboxyl group such as $\mathbf{6}$ and $\mathbf{7}$ were stable in a plasma, they were deacylated in vivo to cytogenin and gave the same metabolites as in the case of cytogenin. Based on these results and from the fact that MC-1 existed without conjugation, we assumed that other compounds having a carboxyl function in the molecule would be stable both in vitro and in vivo. Therefore, the stability of the carboxymethyloxy derivative $\mathbf{1 6}$ and carboxylic acids $\mathbf{2 ,}$ 2a $\sim \mathbf{c}$ and 21a were examined. They showed high stability and remained largely intact both in vitro and in vivo. On the other hand, 9,9-dialkyl carboxamides 21b and 21c were unstable. These findings showed that the carboxylic acid function is crucial for the in vivo stability.

\section{Pharmacological Activities}

Anti-arthritic activities of the derivatives with good in vivo stability were evaluated using type II collagen-induced arthritic mice at a dose of $20 \mathrm{mg} / \mathrm{kg}$ or $30 \mathrm{mg} / \mathrm{kg}$, p.o. The inhibitory activities are shown in Table 2 . The $\mathrm{ED}_{50}$ values of NM-3 and cytogenin were $4.4 \mathrm{mg} / \mathrm{kg} /$ day and $44 \mathrm{mg} / \mathrm{kg}$ / day, respectively.

As indicated by the data in Table 2, the anti-arthritic activity was exhibited by only a few limited compounds, by oral administration. The $\mathrm{C}^{9}-\mathrm{COOH}$ linkage at $\mathrm{C}-3$ is essential for exhibition of the activity. Substitution at the C9 position was effective in strengthening the activity, and the methyl group was most efficacious. The bulkier 
Table 1. Biological stability of cytogenin derivatives in plasma.

\begin{tabular}{ccc}
\hline Compounds & in vitro $(\%)^{1)}$ & $\begin{array}{c}\text { in vivo }{ }^{2)} \\
\text { Conjugation rate (\%) }\end{array}$ \\
\hline Cytogenin & 98.0 & 70 \\
MC-1 & 99.3 & 0 \\
2 & 92.5 & 0 \\
2a (NM-3) & 97.6 & 0 \\
2b & 84.0 & 4 \\
2 c & 90.6 & 8 \\
4 & $0 *$ & n.t. \\
5 & $0 *$ & n.t. \\
6 & 95.4 & $*$ \\
7 & 92.9 & $*$ \\
8 & $0 *$ & n.t. \\
9 & $0 *$ & n.t. \\
10 & $41.1 *$ & n.t. \\
12 & 99.7 & 6 \\
13 & 95.3 & 90 \\
14 & 99.2 & 25 \\
16 & 101 & 25 \\
$21 a$ & 98.4 & 0 \\
$\mathbf{2 1 b}$ & 95.2 & 20 \\
$\mathbf{2 1 c}$ & 80.3 & 70 \\
\hline
\end{tabular}

1): Stability in mouse plasma

2): Metabolism in mice (at $30 \mathrm{~min}$ after $25 \mathrm{mg} / \mathrm{kg}, \mathrm{po}$ ). * : Hydrolized to cytogenin n.t.: not tested

substituents such as ethyl for compound $\mathbf{2} \mathbf{b}$ or dimethyl for compound 21a showed less potent activity.

Anti-angiogenic activity has been found for cytogenin ${ }^{4)}$. So a mouse dorsal air sac assay, as described in the previous report ${ }^{5)}$, was also examined for cytogenin derivatives. As shown in Table 2, compounds 2a (NM-3) and 21 a were more active than cytogenin. NM-3 showed $78 \%$ inhibitory activity against the angiogenesis induced by S-180 tumor cells in mice at a single dose of $10 \mathrm{mg} / \mathrm{kg}$, p.o.

When $25 \mathrm{mg} / \mathrm{kg}$ of NM-3 was orally administered, the maximal blood concentration $\left(C_{\max }\right)$ reached $129.3 \mu \mathrm{g} / \mathrm{ml}$ $\left(\mathrm{T}_{1 / 2}: 3.43\right.$ hour, $\mathrm{T}_{\max }: 0.141$ hour), which was about 100 times higher than that of cytogenin. The area under the curve (AUC) value was $777 \mathrm{mg} \cdot \mathrm{hr} / \mathrm{ml}$.

Furthermore, the acute toxicity test in mice showed that NM-3 had extremely low toxicity (the $\mathrm{LD}_{50}$ value was more than $1 \mathrm{~g} / \mathrm{kg}$ by p.o.). Consequently, NM-3 is the most promising candidate as an orally available therapeutic agent
Table 2. Pharmacological activities of cytogenin derivatives.

\begin{tabular}{ccc}
\hline \multirow{2}{*}{ Compounds } & \multicolumn{2}{c}{ Inhibiting activity (\%) } \\
& Anti-arthritic $^{\text {a) }}$ & Anti-Angiogenic \\
\hline Cytogenin & 38.1 & $60^{\text {b* }}$ \\
MC-1 & 32.6 & $50^{\star \star}$ \\
2 & $3.7^{\star}$ & n.t. \\
2a (NM-3) & 73.6 & 77.8 \\
2b & 6.7 & n.t. \\
2c & 46.4 & 47.3 \\
16 & -1.9 & n.t. \\
21a & 37.6 & 66.4 \\
21b & 18.1 & n.t. \\
\hline
\end{tabular}

a) Inhibitory effect on collagen-induced arthritis at $20 \mathrm{mg} / \mathrm{kg}$ $(*$ at $30 \mathrm{mg} / \mathrm{kg}$ ).

b) Inhibitory effect on S-180-induced angiogenesis at $10 \mathrm{mg} / \mathrm{kg}$ $(\star *$ at $100 \mathrm{mg} / \mathrm{kg})$.

for the treatment of angiogenesis-associated diseases and rheumatoid arthritis.

\section{Experimental}

\section{General}

NMR spectra were recorded on a JEOL JNM-GSX400 spectrometer. Chemical shifts are expressed in $\delta$-value down field from TMS as an internal standard. FAB-MS spectra were measured on a JEOL JMS-SX102A spectrometer using $m$-nitrobenzyl alcohol as a matrix. Silica gel column chromatography was carried out on silica gel 60 (Merck). IR and UV spectra were recorded on a JASCO FT-IR 5300 spectrophotometer and Hitachi model U-3210 spectrophotometer, respectively.

\section{Metabolites of Cytogenin}

Male Sprague-Dawley rats weighing 150 160 g (Japan SLC Inc, Shizuoka, Japan) were fasted overnight before and 8 hours after dosing. After oral administration of cytogenin $(200 \mathrm{mg} / \mathrm{kg})$, rats were kept separately in a glass metabolism cage. Urine was collected for up to 8 hours and analyzed before and after hydrolysis with sulfatase and/or $\alpha$-glucronidase. Briefly, $0.5 \mathrm{ml}$ of urine sample was incubated with either $5 \mathrm{mg}$ of sulfatase (Sigma, S-8629) in $2.0 \mathrm{ml}$ of $0.2 \mathrm{M}$ acetate buffer $(\mathrm{pH} 5.0), 2 \mathrm{mg}$ of $\alpha$ glucronidase (Sigma, G-7646) in $2.0 \mathrm{ml}$ of $0.1 \mathrm{M}$ phosphate buffer ( $\mathrm{pH} 6.8$ ) or $5 \mathrm{mg}$ of sulfatase containing $\alpha$ - 
glucronidase (Sigma, S-9626) in $2.0 \mathrm{ml}$ of $0.2 \mathrm{M}$ acetate buffer (pH 5.0) at $37^{\circ} \mathrm{C}$ for 2 hours. After adding $2.0 \mathrm{ml}$ of saturated ammonium sulfate, the reaction mixture was mixed with $5 \mathrm{ml}$ of ethyl acetate and centrifuged at $1700 \mathrm{~g}$ at $4^{\circ} \mathrm{C}$ for 10 minutes. The resultant supernatant was evaporated in vacuo and the residue was re-dissolved with $1.0 \mathrm{ml}$ of $50 \%$ methanol. Cytogenin and its metabolites in the solution were analyzed by HPLC.

In Vitro and In Vivo Stability Estimation of Cytogenin Analogue

In vitro stability of cytogenin analogs was examined using the plasma taken from ICR mice (Japan SLC Inc, Shizuoka, Japan). The compound was spiked to the plasma $(2.0 \mathrm{ml})$ at $10 \mu \mathrm{g} / \mathrm{ml}$. After adding saturated ammonium sulfate $(1.5 \mathrm{ml})$, the plasma was mixed with $3 \mathrm{ml}$ of ethyl acetate and centrifuged at $1700 \mathrm{~g}$ at $4^{\circ} \mathrm{C}$ for 10 minutes. The resultant supernatant was collected and evaporated in vacuo. The residue was re-dissolved with $0.2 \mathrm{ml}$ of $50 \%$ methanol for the HPLC analysis.

In vivo stability of cytogenin analogue was examined in mice. Male ICR mice weighing 15 17g (Japan SLC Inc., Shizuoka, Japan) were fasted overnight before dosing. After oral administration of the compounds $(25 \mathrm{mg} / \mathrm{kg})$, mice were anesthetized with diethyl ether at 5, 15 and 30 minutes, and blood was drawn from the abdominal aorta. The plasma samples $(0.2 \mathrm{ml})$ obtained by centrifugation of the blood were analyzed before and after hydrolysis with 5 mg sulfatase contains $\alpha$-glucronidase (Sigma, S-9626) in $1.0 \mathrm{ml}$ of $0.2 \mathrm{M}$ acetate buffer ( $\mathrm{pH} 5.0$ ) at $37^{\circ} \mathrm{C}$ for 2 hours. After adding $1.5 \mathrm{ml}$ of saturated ammonium sulfate, the reaction mixture was mixed with $3 \mathrm{ml}$ of ethyl acetate and centrifuged at $1700 \mathrm{~g}$ at $4^{\circ} \mathrm{C}$ for 10 minutes. The resultant supernatant was evaporated in vacuo and the residue was re-dissolved with $0.2 \mathrm{ml}$ of $50 \%$ methanol for the HPLC analysis. The conjugation rate $(\%)$ was calculated as [(Area of the compound after deconjugation by the mixed enzymes-Area of the compound before deconjugation)/ Area of the compound after deconjugation] $\times 100$.

\section{HPLC Analysis}

The HPLC apparatus included two 6-AD HPLC pumps (Shimadzu), a 484 tunable absorbance detector (Waters) and a CHROMATOPAC C-R6A (Shimadzu). YMC-Pack ODS-A A-312 column $(6.0 \times 150 \mathrm{~mm}$, YMC) was used for analysis. The mobile phase was consisted of a solution of $40 \% \mathrm{MeOH}$ as solution $\mathrm{A}$ and $\mathrm{MeOH}$ as solution $\mathrm{B}$, and the columns were eluted with a linear gradient from $0 \%$ to $100 \%$ solution $B(15 \sim 20$ minutes $)$ in a mixture of solution A. The flow rate of the mobile phase was $1.0 \mathrm{ml} / \mathrm{minute}$.
The column effluent was monitored by the ultraviolet absorption at $244 \mathrm{~nm}$.

\section{Anti-arthritic Activity}

Male DBA/1J mice (Charles River Japan, Atsugi, Japan) were used at $8 \sim 12$ weeks of age for the collagen-induced arthritis experiment. The animals were housed under standard laboratory conditions and were fed food and water ad libitum. All compounds used were dissolved or suspended in physiological saline or $0.5 \%$ carboxymethylcellulose (CMC) (Wako Pure Chemical Industries, Osaka, Japan). Bovine type II collagen (Cosmo-Bio, Tokyo, Japan) was dissolved in $0.01 \mathrm{M}$ acetic acid at a concentration of 2 $\mathrm{mg} / \mathrm{ml}$ before use. Mice were immunized by intradermal injection at a base of the tail with $100 \mu \mathrm{g}$ of native collagen emulsified in an equal volume of Freund's complete adjuvant (Difco Labs., Detroit, MI, USA). Three weeks later, mice were boosted by i.p. injection with $100 \mu \mathrm{g}$ of the same emulsified native collagen. Groups of 6 to 10 mice were daily treated p.o. with the compounds at a dose of 20 $\mathrm{mg} / \mathrm{kg} /$ day for 3 weeks after the injection of booster. Groups of 3 and 6 to 10 mice were used for normal control (normal) and arthritis control (control), respectively. Normal and control mice received vehicle alone in the same manner. The mice were observed for clinical arthritis and were scored by grading each paw from 0 to 4 based on erythema and swelling of the joint $(0=$ no erythema or swelling; $1=$ erythema or swelling of one toe; $2=$ erythema or swelling of two or more of the toe; $3=$ erythema and swelling of the entire paw; $4=$ complete erythema and swelling of the entire paw and incapacity to bend the ankle). All four legs were scored; the highest score reached 16 . Inhibitory percent on arthritis was calculated as $[(\mathrm{C}-\mathrm{T})$ $/ \mathrm{C}] \times 100$, where $\mathrm{C}$ was the maximal score of control group and $\mathrm{T}$ was that of treatment group.

\section{Anti-angiogenic Activity}

Anti-angiogenic activity was evaluated using a mouse dorsal air sac assay. The assay was performed as described previously ${ }^{5}$. The compound was administered orally once daily ( 10 or $100 \mathrm{mg} / \mathrm{kg}$ ) for 5 consecutive days to ICR mice (Charles River Japan). And the angiogenic response was assessed by determining the number of newly formed blood vessels, induced by inplanted chamber containing S-180 tumor cells.

3-Chloromethyl-8-hydroxy-6-methoxy-1-oxo- $1 H$-2benzopyran (3)

To a solution of $1(20.0 \mathrm{~g}, 90.09 \mathrm{mmol})$ in THF $(100 \mathrm{ml})$, carbon tetrachloride $(150 \mathrm{ml})$ and triphenylphosphine $(40.3$ 
$\mathrm{g}, 153.2 \mathrm{mmol}$ ) were added. The solution was refluxed for 2 hours and then concentrated. The residue was crystallized from ethanol to give 3 ( $18.9 \mathrm{~g}, 88 \%$ yield).

IR $(\mathrm{KBr}) \mathrm{cm}^{-1} 1685,1165,690 ; \mathrm{UV}(\mathrm{MeOH}) \lambda_{\max } \mathrm{nm}$ (ع) $246(47,900), 333(7,700) ;{ }^{1} \mathrm{H}$ NMR $\left(\mathrm{CDCl}_{3}\right) \delta 10.98$ $(1 \mathrm{H}, \mathrm{s}), 6.54(1 \mathrm{H}, \mathrm{d}, J=2.2 \mathrm{~Hz}), 6.52(1 \mathrm{H}, \mathrm{s}), 6.41(1 \mathrm{H}, \mathrm{d}$, $J=2.2 \mathrm{~Hz}), 4.34(2 \mathrm{H}, \mathrm{s}), 3.88(3 \mathrm{H}, \mathrm{s})$; HR-FABMS $\mathrm{m} / \mathrm{z}$ calcd for $\mathrm{C}_{11} \mathrm{H}_{10} \mathrm{O}_{4} \mathrm{Cl}(\mathrm{M}+\mathrm{H})^{+} 241.0268$, found 241.0275 .

8-Acetoxy-3-hydroxymethyl-6-methoxy-1-oxo-1H-2benzopyran (4)

A mixture of $1(500 \mathrm{mg}, 2.25 \mathrm{mmol})$, pyridine $(0.24 \mathrm{ml}$, $2.92 \mathrm{mmol})$ and acetic anhydride $(0.26 \mathrm{ml}, 2.70 \mathrm{mmol})$ in THF $(2 \mathrm{ml})$ were stirred at room temperature for 15 hours. The reaction mixture was diluted with water and extracted with EtOAc $(50 \mathrm{ml})$. The organic layer was washed with water and brine, dried over $\mathrm{Na}_{2} \mathrm{SO}_{4}$, and then concentrated. The residue was crystallized from methanol to give 4 (302 $\mathrm{mg}, 51 \%$ yield).

IR (KBr) cm $\mathrm{cm}^{-1} 1735,1680,1245 ; \mathrm{UV}(\mathrm{MeOH}) \lambda_{\max } \mathrm{nm}$ (e) $244(46,400), 330(6,500)$; 'H NMR $\left(\mathrm{CDCl}_{3}\right) \delta 11.01$ $(1 \mathrm{H}, \mathrm{s}), 6.53(1 \mathrm{H}, \mathrm{d}, J=2.2 \mathrm{~Hz}), 6.48(1 \mathrm{H}, \mathrm{s}), 6.40(1 \mathrm{H}, \mathrm{d}$, $J=2.2 \mathrm{~Hz}), 4.87(2 \mathrm{H}, \mathrm{s}), 3.88(3 \mathrm{H}, \mathrm{s}), 2.15(3 \mathrm{H}, \mathrm{s})$; HRFABMS $m / z$ calcd for $\mathrm{C}_{13} \mathrm{H}_{13} \mathrm{O}_{6}(\mathrm{M}+\mathrm{H})^{+} 265.0712$, found 265.0704 .

8-Acetoxy-3-acetoxymethyl-6-methoxy-1-oxo-1H-2benzopyran (5)

Compound 5 was prepared by use of a similar procedure analogous to that described for the preparation of 4 except for the amount of reagent $\left(\mathrm{Ac}_{2} \mathrm{O}, 12 \mathrm{eq}\right.$; pyridine, $\left.12 \mathrm{eq}\right)$.

IR $(\mathrm{KBr}) \mathrm{cm}^{-1} 1765,1740,1720,1225$; UV $(\mathrm{MeOH})$ $\lambda_{\max } \mathrm{nm}(\varepsilon) 246(57,200), 316(3,600) ;{ }^{1} \mathrm{H} \mathrm{NMR}\left(\mathrm{CDCl}_{3}\right) \delta$ $6.72(1 \mathrm{H}, \mathrm{d}, J=2.2 \mathrm{~Hz}), 6.71(1 \mathrm{H}, \mathrm{d}, J=2.2 \mathrm{~Hz}), 6.46(1 \mathrm{H}$, s), $4.85(2 \mathrm{H}, \mathrm{s}), 3.90(3 \mathrm{H}, \mathrm{s}), 2.41(3 \mathrm{H}, \mathrm{s}), 2.14(3 \mathrm{H}, \mathrm{s})$; HR-FABMS $m / z$ calcd for $\mathrm{C}_{15} \mathrm{H}_{15} \mathrm{O}_{7}(\mathrm{M}+\mathrm{H})^{+} 307.0818$, found 307.0812 .

8-Hydroxy-6-methoxy-1-oxo-3-succinoyloxymethyl-1H2-benzopyran (6)

To a solution of 1 ( $300 \mathrm{mg}, 1.35 \mathrm{mmol})$ in toluene $(5 \mathrm{ml})$ was added succinic anhydride $(270 \mathrm{mg}, 5.40 \mathrm{mmol})$. After refluxing for 8 hours, the solution was concentrated. The residue was crystallized from methanol to give $6(320 \mathrm{mg}$, $74 \%$ yield).

IR $(\mathrm{KBr}) \mathrm{cm}^{-1} 1720,1680,1650,1165 ; \mathrm{UV}(\mathrm{MeOH})$ $\lambda_{\text {max }} \mathrm{nm}(\varepsilon) 244(53,200), 330(6,600)$; ${ }^{1} \mathrm{H}$ NMR (acetone$\left.d_{6}\right) \delta 11.04(1 \mathrm{H}, \mathrm{s}), 6.78(1 \mathrm{H}, \mathrm{s}), 6.64(1 \mathrm{H}, \mathrm{d}, J=2.2 \mathrm{~Hz})$, $6.55(1 \mathrm{H}, \mathrm{d}, J=2.2 \mathrm{~Hz}), 4.96(2 \mathrm{H}, \mathrm{s}), 3.93(3 \mathrm{H}, \mathrm{s}), 2.70 \sim$ $2.73(2 \mathrm{H}, \mathrm{m}), 2.64 \sim 2.68(2 \mathrm{H}, \mathrm{m})$; HR-FABMS $\mathrm{m} / z$ calcd for $\mathrm{C}_{15} \mathrm{H}_{15} \mathrm{O}_{8}(\mathrm{M}+\mathrm{H})^{+}$323.0767, found 323.0759.

3-Glutamoyloxymethyl-8-hydroxy-6-methoxy-1-oxo-1 $H$ 2-benzopyran (7)

By use of a procedure analogous to that described for the preparation of 6, compound 7 was prepared from 1 and glutamic anhydride ( $77 \%$ yield).

IR $(\mathrm{KBr}) \mathrm{cm}^{-1} 1735,1680,1650,1170 ; \mathrm{UV}(\mathrm{MeOH})$ $\lambda_{\max } \mathrm{nm}(\varepsilon) 244(45,600), 330(6,200) ;{ }^{1} \mathrm{H}$ NMR (acetone$\left.d_{6}\right) \delta 11.04(1 \mathrm{H}, \mathrm{s}), 6.78(1 \mathrm{H}, \mathrm{s}), 6.65(1 \mathrm{H}, \mathrm{d}, J=2.2 \mathrm{~Hz})$, $6.55(1 \mathrm{H}, \mathrm{d}, J=2.2 \mathrm{~Hz}), 4.96(2 \mathrm{H}, \mathrm{s}), 3.93(3 \mathrm{H}, \mathrm{s}), 2.51 \sim$ $2.54(2 \mathrm{H}, \mathrm{m}), 2.38 \sim 2.42(2 \mathrm{H}, \mathrm{m}), 1.89 \sim 1.96(2 \mathrm{H}, \mathrm{m})$; HRFABMS $m / z$ calcd for $\mathrm{C}_{16} \mathrm{H}_{17} \mathrm{O}_{8}(\mathrm{M}+\mathrm{H})^{+} 337.0923$, found for 337.0927 .

8-Hydroxy-6-methoxy-3-phenylacetoxymethyl-1-oxo-1H2-benzopyran (8)

By use of a procedure analogous to that described for the preparation of $\mathbf{4}$, compound 8 was prepared from 1 and phenacyl chloride (74\% yield).

IR $(\mathrm{KBr}) \mathrm{cm}^{-1} 1745,1680,1165 ; \mathrm{UV}(\mathrm{MeOH}) \lambda_{\max } \mathrm{nm}$ (e) $244(52,200), 330(7,100) ;{ }^{1} \mathrm{H}$ NMR $\left(\mathrm{CDCl}_{3}\right) \delta 10.99$ $(1 \mathrm{H}, \mathrm{s}), 7.28 \sim 7.37(5 \mathrm{H}, \mathrm{m}), 6.51(1 \mathrm{H}, \mathrm{d}, J=2.2 \mathrm{~Hz}), 6.31$ $(1 \mathrm{H}, \mathrm{s}), 6.30(1 \mathrm{H}, \mathrm{d}, J=2.2 \mathrm{~Hz}), 4.90(2 \mathrm{H}, \mathrm{s}), 3.87(3 \mathrm{H}, \mathrm{s})$, $3.72(2 \mathrm{H}, \mathrm{s})$; HR-FABMS $m / z$ calcd for $\mathrm{C}_{18} \mathrm{H}_{17} \mathrm{O}_{6}(\mathrm{M}+\mathrm{H})^{+}$ 341.1025 , found 341.1017 .

8-Hydroxy-3-manderoyloxymethyl-6-methoxy-1-oxo$1 H$-2-benzopyran (9)

To a solution of 3 (200 $\mathrm{mg}, 0.83 \mathrm{mmol})$ in DMF ( $1 \mathrm{ml})$, potassium carbonate $(285 \mathrm{mg}, 2.08 \mathrm{mmol})$ and DL-manderic acid $(630 \mathrm{mg}, 4.15 \mathrm{mmol})$ were added. After stirring at $60^{\circ} \mathrm{C}$ for 2 hours, the reaction mixture was diluted with water and extracted with EtOAc $(30 \mathrm{ml})$. The organic layer was washed with water and brine, dried over $\mathrm{Na}_{2} \mathrm{SO}_{4}$, and then concentrated. The residue was purified by silica gel column chromatography to give 9 (234 $\mathrm{mg}, 79 \%$ yield).

IR $(\mathrm{KBr}) \mathrm{cm}^{-1} 1690,1165$; UV $(\mathrm{MeOH}) \lambda_{\max } \mathrm{nm}(\varepsilon)$ 245 (52,300), 330 (7,300); ${ }^{1} \mathrm{H}$ NMR $\left(\mathrm{CDCl}_{3}\right) \delta 10.93(1 \mathrm{H}$, $\mathrm{s}), 7.35 \sim 7.47(5 \mathrm{H}, \mathrm{m}), 6.51(2 \mathrm{H}, \mathrm{d}, J=2.2 \mathrm{~Hz}), 6.24(1 \mathrm{H}, \mathrm{d}$, $J=2.2 \mathrm{~Hz}), 6.09(1 \mathrm{H}, \mathrm{s}), 5.29(1 \mathrm{H}, \mathrm{d}, J=5.8 \mathrm{~Hz}), 4.96(2 \mathrm{H}$, s), $3.87(3 \mathrm{H}, \mathrm{s}), 3.31(1 \mathrm{H}, \mathrm{d}, J=5.8 \mathrm{~Hz})$; HR-FABMS $m / z$ calcd for $\mathrm{C}_{19} \mathrm{H}_{17} \mathrm{O}_{7}(\mathrm{M}+\mathrm{H})^{+} 357.0974$, found 357.0949 .

3-(2-Aminoisovaleroyloxy)methyl-8-hydroxy-6-methoxy1-oxo-1H-2-benzopyran (10)

A solution of $3(300 \mathrm{mg}, 1.35 \mathrm{mmol})$, potassium carbonate $(273 \mathrm{mg}, 2.03 \mathrm{mmol})$ and Boc-valine $(580 \mathrm{mg}, 2.70$ $\mathrm{mmol})$ in DMF $(5 \mathrm{ml})$ was stirred at $80^{\circ} \mathrm{C}$ for 2 hours. The reaction mixture was diluted with water and extracted with 
EtOAc $(50 \mathrm{ml})$. The organic layer was washed with water and brine, dried over $\mathrm{Na}_{2} \mathrm{SO}_{4}$, and then concentrated. The residue was purified by silica gel column chromatography to give $N$-Boc derivative of $\mathbf{1 0}(510 \mathrm{mg})$. To a solution of this compound in $\mathrm{CH}_{2} \mathrm{Cl}_{2}(10 \mathrm{ml})$ was added TFA $(1 \mathrm{ml})$. After stirring at room temperature for 10 hours, the reaction mixture was concentrated. The residue was diluted with EtOAc $(50 \mathrm{ml})$, washed successively with saturated sodium bicarbonate, water and brine. The organic layer was dried over $\mathrm{Na}_{2} \mathrm{SO}_{4}$ and concentrated to give 10 (237 $\mathrm{mg}, 55 \%$ yield).

IR (KBr) cm $\mathrm{cm}^{-1} 1690,1620,1165 ; \mathrm{UV}(\mathrm{MeOH}) \lambda_{\max } \mathrm{nm}$ (ع) $244(50,500), 330(7,100) ;{ }^{1} \mathrm{H}$ NMR $\left(\mathrm{CD}_{3} \mathrm{OD}\right) \delta 6.86$ $(1 \mathrm{H}, \mathrm{s}), 6.70(1 \mathrm{H}, \mathrm{d}, J=2.2 \mathrm{~Hz}), 6.60(1 \mathrm{H}, \mathrm{d}, J=2.2 \mathrm{~Hz})$, $4.99(1 \mathrm{H}, \mathrm{d}, J=13.2 \mathrm{~Hz}), 4.94(1 \mathrm{H}, \mathrm{d}, J=13.2 \mathrm{~Hz}), 3.87$ $(3 \mathrm{H}, \mathrm{s}), 3.21(1 \mathrm{H}, \mathrm{d}, J=5.9 \mathrm{~Hz}), 1.84 \sim 1.92(1 \mathrm{H}, \mathrm{m}), 0.89$ $(3 \mathrm{H}, \mathrm{d}, J=6.6 \mathrm{~Hz}), 0.84(3 \mathrm{H}, \mathrm{d}, J=6.6 \mathrm{~Hz})$; HR-FABMS $m / z$ calcd for $\mathrm{C}_{16} \mathrm{H}_{20} \mathrm{NO}_{6}(\mathrm{M}+\mathrm{H})^{+}$322.1291, found 322.1310 .

3-(2,6-Diaminohexanoyloxy)methyl-8-hydroxy-6-methoxy1-oxo-1H-2-benzopyran (11)

By use of a procedure analogous to that described for the preparation of $\mathbf{1 0}$, compound $\mathbf{1 1}$ was prepared from $\mathbf{1}$ and $N, N^{\prime}$-di-Boc-lysine as trifluoroacetic acid salt ( $77 \%$ yield).

IR (KBr) cm $\mathrm{cm}^{-1} 1690,1620,1200$; UV (MeOH) $\lambda_{\max } \mathrm{nm}$ (ع) $245(40,800), 331(5,600) ;{ }^{1} \mathrm{H}$ NMR (DMSO- $\left.d_{6}\right) \delta$ $10.89(1 \mathrm{H}, \mathrm{s}), 8.48(2 \mathrm{H}, \mathrm{br}), 7.73(2 \mathrm{H}, \mathrm{br}), 6.93(1 \mathrm{H}, \mathrm{s})$, $6.71(1 \mathrm{H}, \mathrm{d}, J=2.2 \mathrm{~Hz}), 6.64(1 \mathrm{H}, \mathrm{d}, J=2.2 \mathrm{~Hz}), 5.14(1 \mathrm{H}$, d, $J=13.2 \mathrm{~Hz}), 5.09(1 \mathrm{H}, \mathrm{d}, J=13.2 \mathrm{~Hz}), 4.15(1 \mathrm{H}, \mathrm{br}), 3.88$ $(3 \mathrm{H}, \mathrm{s}), 2.76(2 \mathrm{H}, \mathrm{br}), 1.79 \sim 1.84(2 \mathrm{H}, \mathrm{m}), 1.33 \sim 1.58(4 \mathrm{H}$, $\mathrm{m})$; HR-FABMS $\mathrm{m} / \mathrm{z}$ calcd for $\mathrm{C}_{17} \mathrm{H}_{23} \mathrm{~N}_{2} \mathrm{O}_{6}(\mathrm{M}+\mathrm{H})^{+}$ 351.1556 , found 351.1560 .

6,8-Dimethoxy-3-methoxymethyl-1-oxo-1H-2-benzopyran (12)

To a solution of $1(1.00 \mathrm{~g}, 4.50 \mathrm{mmol})$ in DMF $(15 \mathrm{ml})$, sodium hydride $(60 \%$, in oil, $540 \mathrm{mg}, 13.5 \mathrm{mmol})$ and methyl iodide $(3.6 \mathrm{ml}, 27.0 \mathrm{mmol})$ were added. After stirring at room temperature for 15 hours, the reaction mixture was diluted with water and extracted with EtOAc $(100 \mathrm{ml})$. The organic layer was washed with water and brine, dried over $\mathrm{Na}_{2} \mathrm{SO}_{4}$, and then concentrated. Chromatographic separation followed by recrystallization from EtOH gave 12 (235 mg, 21\% yield).

IR (KBr) cm $\mathrm{cm}^{-1} 1730,1680,1210,1120 ; \mathrm{UV}(\mathrm{MeOH})$ $\lambda_{\max } \mathrm{nm}(\varepsilon) 244(50,400), 326(7,300) ;{ }^{1} \mathrm{H} \mathrm{NMR}\left(\mathrm{CDCl}_{3}\right) \delta$ $6.47(1 \mathrm{H}, \mathrm{d}, J=2.2 \mathrm{~Hz}), 6.39(1 \mathrm{H}, \mathrm{d}, J=2.2 \mathrm{~Hz}), 6.37(1 \mathrm{H}$, s), $4.23(2 \mathrm{H}, \mathrm{s}), 3.98(3 \mathrm{H}, \mathrm{s}), 3.90(3 \mathrm{H}, \mathrm{s}), 3.48(3 \mathrm{H}, \mathrm{s})$; HR-FABMS $m / z$ calcd for $\mathrm{C}_{13} \mathrm{H}_{15} \mathrm{O}_{5}(\mathrm{M}+\mathrm{H})^{+} 251.0919$, found 251.0917 .

8-Hydroxy-6-methoxy-3-methoxymethyl-1-oxo- $1 H$-2benzopyran (13)

To a solution of $12(431 \mathrm{mg}, 1.72 \mathrm{mmol})$ in $\mathrm{CH}_{2} \mathrm{Cl}_{2}(10$ $\mathrm{ml}$ ) was added boron trichloride $\left(1 \mathrm{M} \mathrm{CH}_{2} \mathrm{Cl}_{2}\right.$ sol., $\left.3.5 \mathrm{ml}\right)$ at $-35^{\circ} \mathrm{C}$. After stirring at the same temperature for 30 minutes and further at room temperature for 1 hour, the reaction mixture was diluted with water and extracted with $\mathrm{CH}_{2} \mathrm{Cl}_{2}(10 \mathrm{ml})$. The organic layer was washed with water and brine, dried over $\mathrm{Na}_{2} \mathrm{SO}_{4}$ and then concentrated. The residue was recrystallized from EtOH to give $13(231 \mathrm{mg}$, $57 \%$ yield).

IR $(\mathrm{KBr}) \mathrm{cm}^{-1} 1700,1240,1120 ; \mathrm{UV}(\mathrm{MeOH}) \lambda_{\max } \mathrm{nm}$ (c) $243(47,000), 330(6,700)$; ${ }^{1} \mathrm{H}$ NMR $\left(\mathrm{CDCl}_{3}\right) \delta 11.05$ $(1 \mathrm{H}, \mathrm{s}), 6.50(1 \mathrm{H}, \mathrm{d}, J=2.2 \mathrm{~Hz}), 6.46(1 \mathrm{H}, \mathrm{s}), 6.38(1 \mathrm{H}, \mathrm{d}$, $J=2.2 \mathrm{~Hz}), 4.24(2 \mathrm{H}, \mathrm{s}), 3.87(3 \mathrm{H}, \mathrm{s}), 3.48(3 \mathrm{H}, \mathrm{s})$; HRFABMS $m / z$ calcd for $\mathrm{C}_{12} \mathrm{H}_{13} \mathrm{O}_{5}(\mathrm{M}+\mathrm{H})^{+} 237.0763$, found 237.0765 .

3-Hydroxymethyl-8-carboxymethyloxy-6-methoxy-1-oxo1H-2-benzopyran (14)

A solution of $1(330 \mathrm{mg}, 1.50 \mathrm{mmol})$, potassium carbonate $(330 \mathrm{mg}, 2.25 \mathrm{mmol})$ and $t$-butyl bromoacetate $(1.1 \mathrm{ml}, 7.50 \mathrm{mmol})$ in DMF $(5 \mathrm{ml})$ was stirred at room temperature for 19 hours. The reaction mixture was diluted with water and extracted with EtOAc $(100 \mathrm{ml})$. The organic layer was washed with water and brine, dried over $\mathrm{Na}_{2} \mathrm{SO}_{4}$, and then concentrated. The residue was purified by silica gel column chromatography to give $t$-butyl ester of $\mathbf{1 4}$ (501 $\mathrm{mg})$. To a solution of the $t$-butyl ester $(501 \mathrm{mg})$ in $\mathrm{CH}_{2} \mathrm{Cl}_{2}$ $(5 \mathrm{ml})$ was added TFA $(1 \mathrm{ml})$. After stirring at room temperature for 2 hours, the reaction mixture was concentrated. Crystallization from $\mathrm{MeOH}(5 \mathrm{ml})$ gave 14 (211 mg, 51\% yield).

IR $(\mathrm{KBr}) \mathrm{cm}^{-1} 1755,1695,1210,1090 ; \mathrm{UV}(\mathrm{MeOH})$ $\lambda_{\max } \mathrm{nm}(\varepsilon) 244(53,500), 333(7,100) ;{ }^{1} \mathrm{H}$ NMR (DMSO$\left.d_{6}\right) \delta 6.74(1 \mathrm{H}, \mathrm{d}, J=2.2 \mathrm{~Hz}), 6.54(1 \mathrm{H}, \mathrm{s}), 6.46(1 \mathrm{H}, \mathrm{d}, J=$ $2.2 \mathrm{~Hz}), 5.59(1 \mathrm{H}, \mathrm{s}), 4.86(2 \mathrm{H}, \mathrm{s}), 4.22(1 \mathrm{H}, \mathrm{s}), 3.85(3 \mathrm{H}$, s). HR-FABMS $m / z$ calcd for $\mathrm{C}_{13} \mathrm{H}_{13} \mathrm{O}_{7}(\mathrm{M}+\mathrm{H})^{+} 281.0661$, found 281.0662 .

3-Hydroxymethyl-6-methoxy-8-methoxymethyloxy-1-oxo1H-2-benzopyran (15)

To a solution of $3(500 \mathrm{mg}, 2.25 \mathrm{mmol})$ in DMF $(10 \mathrm{ml})$, sodium hydride $(60 \%$, in oil, $166 \mathrm{mg}, 4.15 \mathrm{mmol})$ and chloromethylmethylether $(0.80 \mathrm{ml}, 10.24 \mathrm{mmol})$ were added at $0^{\circ} \mathrm{C}$. After stirring at room temperature for 2 hours, the reaction mixture was diluted with water and extracted with EtOAc $(100 \mathrm{ml})$. The organic layer was washed with water 
and brine, dried over $\mathrm{Na}_{2} \mathrm{SO}_{4}$, and then concentrated. To a solution of the residue in DMF $(10 \mathrm{ml})$ was added sodium formate $(1.40 \mathrm{~g}, 10.3 \mathrm{mmol})$ and the solution was stirred at $80^{\circ} \mathrm{C}$ for 2 hours. The reaction mixture was diluted with water and extracted with EtOAc $(100 \mathrm{ml})$. The organic layer was washed with water and brine, dried over $\mathrm{Na}_{2} \mathrm{SO}_{4}$, and then concentrated. The residue in acetonitrile was treated with sodium bicarbonate $(10 \mathrm{ml})$ at $40^{\circ} \mathrm{C}$ for 17 hours. The reaction mixture was diluted with EtOAc $(100 \mathrm{ml})$, which was washed with water and brine, dried over $\mathrm{Na}_{2} \mathrm{SO}_{4}$ and concentrated to give $\mathbf{1 5}$ ( $526 \mathrm{mg}, 88 \%$ yield).

IR $(\mathrm{KBr}) \mathrm{cm}^{-1} 1700,1160,1050$; UV (MeOH) $\lambda_{\max } \mathrm{nm}$ (ع) $244(40,700), 321(4,100)$; ${ }^{1} \mathrm{H}$ NMR $\left(\mathrm{CDCl}_{3}\right) \delta 6.77$ $(1 \mathrm{H}, \mathrm{d}, J=2.2 \mathrm{~Hz}), 6.46(1 \mathrm{H}, \mathrm{d}, J=2.2 \mathrm{~Hz}), 6.37(1 \mathrm{H}, \mathrm{s})$, $5.35(2 \mathrm{H}, \mathrm{s}), 4.44(2 \mathrm{H}, \mathrm{d}, J=6.6 \mathrm{~Hz}), 3.88(3 \mathrm{H}, \mathrm{s}), 3.55$ $(3 \mathrm{H}, \mathrm{s}), 2.22(1 \mathrm{H}, \mathrm{t}, J=6.6 \mathrm{~Hz})$. HR-FABMS $\mathrm{m} / z$ calcd for $\mathrm{C}_{13} \mathrm{H}_{15} \mathrm{O}_{6}(\mathrm{M}+\mathrm{H})^{+}$267.0869, found 267.0869.

3-Carboxymethyloxymethyl-8-hydroxy-6-methoxy-1-oxo$1 H$-2-benzopyran (16)

To a solution of 15 ( $300 \mathrm{mg}, 1.13 \mathrm{mmol})$ in DMF $(10 \mathrm{ml})$, sodium hydride $(136 \mathrm{mg}, 3.40 \mathrm{mmol})$ and bromoacetic acid $t$-butyl ester $(0.83 \mathrm{ml}, 5.66 \mathrm{mmol})$ were added at $0^{\circ} \mathrm{C}$. After stirring at room temperature for 2 hours, the reaction mixture was diluted with water and extracted with EtOAc $(100 \mathrm{ml})$. The organic layer was washed with water and brine, dried over $\mathrm{Na}_{2} \mathrm{SO}_{4}$, and then concentrated. After chromatographic purification, the ester was dissolved in acetonitrile $(10 \mathrm{ml})$ and was treated with $1 \mathrm{M} \mathrm{HCl}(10 \mathrm{ml})$ at $40^{\circ} \mathrm{C}$ for 1 hour. The reaction mixture was diluted with EtOAc $(50 \mathrm{ml})$, which was washed with water and brine, dried over $\mathrm{Na}_{2} \mathrm{SO}_{4}$, and then concentrated. To a solution of the residue in $\mathrm{CH}_{2} \mathrm{Cl}_{2}(5 \mathrm{ml})$ was added TFA $(1 \mathrm{ml})$, and the solution was stirred at room temperature for 2 hours. The reaction mixture was added water and extracted with EtOAc $(50 \mathrm{ml})$. The organic layer was washed with water and brine, dried over $\mathrm{Na}_{2} \mathrm{SO}_{4}$ and concentrated. Crystallization from EtOAc ( $10 \mathrm{ml}$ ) gave 16 ( $140 \mathrm{mg}, 44 \%$ yield).

IR $(\mathrm{KBr}) \mathrm{cm}^{-1} 1730,1680,1165,1130$; UV (MeOH) $\lambda_{\max } \mathrm{nm}(\varepsilon) 244(48,500), 330(6,700)$; 'H NMR (DMSO$\left.d_{6}\right) \delta 10.94(1 \mathrm{H}, \mathrm{s}), 6.78(1 \mathrm{H}, \mathrm{s}), 6.69(1 \mathrm{H}, \mathrm{d}, J=2.2 \mathrm{~Hz})$, $6.58(1 \mathrm{H}, \mathrm{d}, J=2.2 \mathrm{~Hz}), 4.39(2 \mathrm{H}, \mathrm{s}), 4.15(2 \mathrm{H}, \mathrm{s}), 3.87$ $(3 \mathrm{H}, \mathrm{s})$. HR-FABMS $\mathrm{m} / \mathrm{z}$ calcd for $\mathrm{C}_{13} \mathrm{H}_{13} \mathrm{O}_{7}(\mathrm{M}+\mathrm{H})^{+}$ 281.0661, found 281.0637 .

3-Carboxy-8-hydroxy-6-methoxy-1-oxo-1H-2-benzopyran (MC-1)

To a solution of $1(3.6 \mathrm{~g}, 16.2 \mathrm{mmol})$ in acetone $(100 \mathrm{ml})$ was added Jones' reagent $(14 \mathrm{ml})$ at $0^{\circ} \mathrm{C}$. After stirring at the same temperature for 10 minutes, the mixture was diluted with water $(500 \mathrm{ml})$ and extracted with EtOAc. The organic layer was washed with $20 \%$ aq. $\mathrm{NaCl}(200 \mathrm{ml} \times 3)$. The extract was back-extracted with $5 \% \mathrm{NaHCO}_{3}(300$ $\mathrm{ml} \times 4$ ). The volume of the aqueous solution was adjusted to $1400 \mathrm{ml}$ by addition of water, and acidified to $\mathrm{pH} 3$ with conc. $\mathrm{HCl}$. The white precipitate $(2.36 \mathrm{~g})$ formed was obtained by filtration, while $150 \mathrm{mg}$ of MC-1 was recovered from EtOAc extract of the mother liquid. The combined solid was washed with hot $90 \%$ aq. $\mathrm{MeOH}(40 \mathrm{ml})$ to give pure $\mathrm{MC}-1(2.36 \mathrm{~g}, 62 \%$ yield $)$.

IR $(\mathrm{KBr}) \mathrm{cm}^{-1} 3436,1723,1692,1616,1377,1196$, 1173 ; ${ }^{1} \mathrm{H}$ NMR (DMSO-d $d_{6} \delta 10.89(1 \mathrm{H}, \mathrm{s}), 7.59(1 \mathrm{H}, \mathrm{s})$, $6.96(1 \mathrm{H}, \mathrm{d}, J=2.4 \mathrm{~Hz}), 6.71(1 \mathrm{H}, \mathrm{d}, J=2.4 \mathrm{~Hz}), 3.88(3 \mathrm{H}$, $\mathrm{s}) ;{ }^{13} \mathrm{C}$ NMR (DMSO- $d_{6}$ ) $\delta 56.0,100.9,102.7,104.5$, 112.6, 137.1, 143.2, 160.7, 162.5, 163.8, 166.3; FAB-MS $m / z 237(\mathrm{M}+\mathrm{H})^{+}$.

3-Cyanomethyl-8-hydroxy-6-methoxy-1-oxo- $1 \mathrm{H}-2$ benzopyran (17)

A solution of $3(5.00 \mathrm{~g}, 20.8 \mathrm{mmol})$ and sodium cyanide $(4.09 \mathrm{~g}, 83.3 \mathrm{mmol})$ in DMSO $(250 \mathrm{ml})$ was stirred at room temperature for 1 hour under a nitrogen atmosphere. The reaction mixture was diluted with water and extracted with EtOAc $(500 \mathrm{ml} \times 3)$. The organic layer was washed with $20 \%$ brine $(400 \mathrm{ml} \times 3)$, dried over $\mathrm{Na}_{2} \mathrm{SO}_{4}$, and then concentrated. The residue was dissolved in hot EtOH (50 $\mathrm{ml}$ ) and the solution was stirred at room temperature for 1 hour. The precipitate was collected by filtration, dried in vacuo to give $\mathbf{1 7}$ ( $4.02 \mathrm{~g}, 84 \%$ yield).

IR (KBr) cm $\mathrm{cm}^{-1} 2260,1680,1195 ; \mathrm{UV}(\mathrm{MeOH}) \lambda_{\max } \mathrm{nm}$ (c) $244(44,700), 329(6,600)$; ' $\mathrm{H}$ NMR $\left(\mathrm{CDCl}_{3}\right) \delta 10.82$ $(1 \mathrm{H}, \mathrm{s}), 6.58(1 \mathrm{H}, \mathrm{s}), 6.54(1 \mathrm{H}, \mathrm{d}, J=2.2 \mathrm{~Hz}), 6.42(1 \mathrm{H}, \mathrm{d}$, $J=2.2 \mathrm{~Hz}), 3.89(3 \mathrm{H}, \mathrm{s}), 3.65(2 \mathrm{H}, \mathrm{s})$; HR-FABMS $\mathrm{m} / \mathrm{z}$ calcd for $\mathrm{C}_{13} \mathrm{H}_{10} \mathrm{NO}_{4}(\mathrm{M}+\mathrm{H})^{+} 232.0610$, found 232.0598 .

(8-Hydroxy-6-methoxy-1-oxo-1 $H$-2-benzopyran-3-yl)acetic acid (2)

To a solution of $17(1.50 \mathrm{~g}, 6.49 \mathrm{mmol})$ in $\mathrm{AcOH}(12 \mathrm{ml})$ was added conc. $\mathrm{HCl}(12 \mathrm{ml})$, and stirred at $80^{\circ} \mathrm{C}$ for 8 hours. Water $(9 \mathrm{ml})$ was added to the solution and stirred at room temperature for 15 hours. The precipitate was collected by filtration, washed with water, and then dried in vacuo to give crude 2. The crude 2 was dissolved in $\mathrm{EtOH}$ $(30 \mathrm{ml})$ and added charcoal $(1.00 \mathrm{~g})$. The solution was stirred at $60^{\circ} \mathrm{C}$ for 1 hour and concentrated after filtration. Recrystallization from acetone-hexane (1:5) gave 2 (1.12 g, 69\% yield).

IR (KBr) cm $\mathrm{cm}^{-1} 1720,1690,1240 ; \mathrm{UV}(\mathrm{MeOH}) \lambda_{\max } \mathrm{nm}$ (ع) $245(47,200), 329(6,300) ;{ }^{1} \mathrm{H}$ NMR (DMSO- $\left.d_{6}\right) \delta$ $10.93(1 \mathrm{H}, \mathrm{s}), 6.66(1 \mathrm{H}, \mathrm{s}), 6.63(1 \mathrm{H}, \mathrm{d}, J=2.2 \mathrm{~Hz}), 6.56$ 
$(1 \mathrm{H}, \mathrm{d}, J=2.2 \mathrm{~Hz}), 3.86(3 \mathrm{H}, \mathrm{s}), 3.62(2 \mathrm{H}, \mathrm{s})$. HR-FABMS $m / z$ calcd for $\mathrm{C}_{12} \mathrm{H}_{11} \mathrm{O}_{6}(\mathrm{M}+\mathrm{H})^{+}$251.0556, found 251.0557 .

8-t-Butyldimethylsilyloxy-3-cyanomethyl-6-methoxy-1-oxo$1 H$-2-benzopyran (18)

To a solution of crude 17, which was prepared from 21.6 $\mathrm{g}$ of 3 , in DMF (200 ml), imidazole (12.2 g, $180.2 \mathrm{mmol})$ and $t$-butyldimethylchlorosilane $(21.8 \mathrm{~g}, 144.1 \mathrm{mmol})$ were added at $0^{\circ} \mathrm{C}$ and the solution was stirred at the same temperature for 2 hours. The reaction mixture was diluted with water and extracted with toluene $(400 \mathrm{ml})$. The organic layer was washed with water and brine, dried over $\mathrm{Na}_{2} \mathrm{SO}_{4}$, and then concentrated. The residue was crystallized from ethanol to give $\mathbf{1 8}$ ( $24.3 \mathrm{~g}, 75 \%$ yield).

IR (KBr) cm ${ }^{-1} 2260,1740,1170,835 ; \mathrm{UV}(\mathrm{MeOH}) \lambda_{\max }$ $\mathrm{nm}(\varepsilon) 244(56,600), 323(6,100) ;{ }^{1} \mathrm{H}$ NMR $\left(\mathrm{CDCl}_{3}\right) \delta 6.48$ $(1 \mathrm{H}, \mathrm{s}), 6.46(1 \mathrm{H}, \mathrm{d}, J=2.2 \mathrm{~Hz}), 6.45(1 \mathrm{H}, \mathrm{d}, J=2.2 \mathrm{~Hz})$, $3.87(3 \mathrm{H}, \mathrm{s}), 3.59(2 \mathrm{H}, \mathrm{s}), 1.05(9 \mathrm{H}, \mathrm{s}), 0.27(6 \mathrm{H}, \mathrm{s})$; HRFABMS $m / z$ calcd for $\mathrm{C}_{18} \mathrm{H}_{24} \mathrm{NO}_{4} \mathrm{Si}(\mathrm{M}+\mathrm{H})^{+} 346.1475$, found 346.1454 .

8-t-Butyldimethylsilyloxy-3-(1-cyanoethyl)-6-methoxy1-oxo-1H-2-benzopyran (19a)

To a vigorously stirred solution of $18(10.0 \mathrm{~g}, 29.0 \mathrm{mmol})$ in two phase system of $\mathrm{CH}_{2} \mathrm{Cl}_{2}(200 \mathrm{ml})-1 \mathrm{M} \mathrm{NaOH}(200$ $\mathrm{ml})$, tetra- $n$-butyl ammonium bromide $(2.34 \mathrm{~g}, 7.25 \mathrm{mmol})$ and methyl iodide $(7.2 \mathrm{ml}, 115.9 \mathrm{mmol})$ were added and the solution was stirred at $0^{\circ} \mathrm{C}$ for 1 hour. The organic layer was separated, washed with water and brine, dried over $\mathrm{Na}_{2} \mathrm{SO}_{4}$ and concentrated. The residue was purified by silica gel column chromatography to give $19 \mathbf{a}$ ( $4.79 \mathrm{~g}, 46 \%$ yield).

IR $(\mathrm{KBr}) \mathrm{cm}^{-1} 2240,1740,1170,840 ; \mathrm{UV}(\mathrm{MeOH}) \lambda_{\max }$ $\mathrm{nm}(\varepsilon) 244(51,500), 323(5,500) ;{ }^{1} \mathrm{H} \mathrm{NMR}\left(\mathrm{CDCl}_{3}\right) \delta 6.48$ $(1 \mathrm{H}, \mathrm{s}), 6.46(1 \mathrm{H}, \mathrm{d}, J=2.2 \mathrm{~Hz}), 6.45(1 \mathrm{H}, \mathrm{d}, J=2.2 \mathrm{~Hz})$, $3.87(3 \mathrm{H}, \mathrm{s}), 3.73(1 \mathrm{H}, \mathrm{q}, J=7.0 \mathrm{~Hz}), 1.69(3 \mathrm{H}, \mathrm{d}, J=7.0$ $\mathrm{Hz}), 1.06(9 \mathrm{H}, \mathrm{s}), 0.28(6 \mathrm{H}, \mathrm{s})$; HR-FABMS $\mathrm{m} / \mathrm{z}$ calcd for $\mathrm{C}_{19} \mathrm{H}_{26} \mathrm{NO}_{4} \mathrm{Si}(\mathrm{M}+\mathrm{H})^{+} 360.1631$, found 360.1617 .

8-t-Butyldimethylsilyloxy-3-(1-cyanopropyl)-6-methoxy1-oxo-1H-2-benzopyran (19b)

By use of a procedure analogous to that described for the preparation of $19 \mathrm{a}, 19 \mathrm{~b}$ was prepared from 18 and ethyl bromide ( $26 \%$ yield).

IR (KBr) cm $\mathrm{cm}^{-1} 2250,1740,1170,840 ; \mathrm{UV}(\mathrm{MeOH}) \lambda_{\text {max }}$ $\mathrm{nm}(\varepsilon) 245(60,000), 324(6,600) ;{ }^{1} \mathrm{H} \mathrm{NMR}\left(\mathrm{CDCl}_{3}\right) \delta 6.49$ $(1 \mathrm{H}, \mathrm{s}), 6.46(1 \mathrm{H}, \mathrm{d}, J=2.2 \mathrm{~Hz}), 6.45(1 \mathrm{H}, \mathrm{d}, J=2.2 \mathrm{~Hz})$, $3.87(3 \mathrm{H}, \mathrm{s}), 3.66(1 \mathrm{H}, \mathrm{dd}, J=5.1$ and $8.8 \mathrm{~Hz}), 1.98 \sim 2.14$ $(2 \mathrm{H}, \mathrm{m}), 1.12(3 \mathrm{H}, \mathrm{t}, J=7.3 \mathrm{~Hz}), 1.06(9 \mathrm{H}, \mathrm{s}), 0.28(6 \mathrm{H}, \mathrm{s})$; HR-FABMS $m / z$ calcd for $\mathrm{C}_{20} \mathrm{H}_{28} \mathrm{NO}_{4} \mathrm{Si} \quad(\mathrm{M}+\mathrm{H})^{+}$
374.1788, found 374.1784 .

8-t-Butyldimethylsilyloxy-3-(1-cyano-2-phenyl)ethyl-6methoxy-1-oxo-1H-2-benzopyran (19c)

By use of a procedure analogous to that described for the preparation of 19a, 19c was prepared from 18 and benzyl bromide ( $20 \%$ yield).

IR (KBr) $\mathrm{cm}^{-1} 2250,1740,1600,1170,840$; UV $(\mathrm{MeOH}) \lambda_{\max } \mathrm{nm}(\varepsilon) 246(55,000), 325(6,200) ;{ }^{1} \mathrm{H}$ NMR $\left(\mathrm{CDCl}_{3}\right) \delta 7.24 \sim 7.33(5 \mathrm{H}, \mathrm{m}), 6.45(1 \mathrm{H}, \mathrm{d}, J=2.2 \mathrm{~Hz})$, $6.39(1 \mathrm{H}, \mathrm{d}, J=2.2 \mathrm{~Hz}), 6.36(1 \mathrm{H}, \mathrm{s}), 3.90(1 \mathrm{H}, \mathrm{dd}, J=5.1$ and $8.8 \mathrm{~Hz}), 3.85(3 \mathrm{H}, \mathrm{s}), 3.39(1 \mathrm{H}, \mathrm{dd}, J=5.1$ and 13.6 $\mathrm{Hz}), 3.21(1 \mathrm{H}, \mathrm{dd}, J=8.8$ and $13.6 \mathrm{~Hz}), 1.07$ (9H, s), 0.29 $(6 \mathrm{H}, \mathrm{s})$; HR-FABMS $m / z$ calcd for $\mathrm{C}_{25} \mathrm{H}_{30} \mathrm{NO}_{4} \mathrm{Si}(\mathrm{M}+\mathrm{H})^{+}$ 436.1944 , found 436.1917 .

8-t-Butyldimethylsilyloxy-3-(1-cyano-1-methyl)ethyl-6methoxy-1-oxo-1 $H$-2-benzopyran (20a)

To a solution of 18 ( $400 \mathrm{mg}, 1.16 \mathrm{mmol})$ in THF $(4 \mathrm{ml})$, sodium hydride $(60 \%$, in oil, $116 \mathrm{mg}, 2.90 \mathrm{mmol})$ and methyl iodide $(0.44 \mathrm{ml}, 6.96 \mathrm{mmol})$ were added at $-30^{\circ} \mathrm{C}$. After stirring at the same temperature for 1 hour, the reaction mixture was diluted with water and extracted with EtOAc $(100 \mathrm{ml})$. The organic layer was washed with water and brine, dried over $\mathrm{Na}_{2} \mathrm{SO}_{4}$, and then concentrated. The residue was purified by silica gel column chromatography to give $20 a$ (398 $\mathrm{mg}, 92 \%$ yield).

IR $(\mathrm{KBr}) \mathrm{cm}^{-1} 2240,1745,1600,1170,840$; UV $(\mathrm{MeOH}) \lambda_{\max } \mathrm{nm}(\varepsilon) 245(54,600), 323(6,000) ;{ }^{1} \mathrm{H}$ NMR $\left(\mathrm{CDCl}_{3}\right) \delta 6.56(1 \mathrm{H}, \mathrm{s}), 6.47(1 \mathrm{H}, \mathrm{d}, J=2.2 \mathrm{~Hz}), 6.44(1 \mathrm{H}$, d, $J=2.2 \mathrm{~Hz}), 3.87(3 \mathrm{H}, \mathrm{s}), 1.72(6 \mathrm{H}, \mathrm{s}), 1.07(9 \mathrm{H}, \mathrm{s}), 0.29$ $(6 \mathrm{H}, \mathrm{s})$; HR-FABMS $m / z$ calcd for $\mathrm{C}_{20} \mathrm{H}_{28} \mathrm{NO}_{4} \mathrm{Si}(\mathrm{M}+\mathrm{H})^{+}$ 374.1788 , found 374.1776 .

8-t-Butyldimethylsilyloxy-3-(1-cyano-1-propyl)butyl-6methoxy-1-oxo-1H-2-benzopyran (20b)

By use of a procedure analogous to that described for the preparation of $\mathbf{2 0 a}, \mathbf{2 0 b}$ was prepared from 18 and propyl iodide ( $82 \%$ yield).

IR $(\mathrm{KBr}) \mathrm{cm}^{-1} 1735,1600,840 ; \mathrm{UV}(\mathrm{MeOH}) \lambda_{\max } \mathrm{nm}$ (E) $245(54,500), 324(6,100) ;{ }^{1} \mathrm{H}$ NMR $\left(\mathrm{CDCl}_{3}\right) \delta 6.60$ $(1 \mathrm{H}, \mathrm{s}), 6.45(1 \mathrm{H}, \mathrm{d}, J=2.2 \mathrm{~Hz}), 6.43(1 \mathrm{H}, \mathrm{d}, J=2.2 \mathrm{~Hz})$, $3.87(3 \mathrm{H}, \mathrm{s}), 2.04(2 \mathrm{H}, \mathrm{dt}, J=5.2$ and $14.0 \mathrm{~Hz}), 1.82(2 \mathrm{H}$, $\mathrm{dt}, J=5.2$ and $14.0 \mathrm{~Hz}), 1.49 \sim 1.59(2 \mathrm{H}, \mathrm{m}), 1.25 \sim 1.34$ $(2 \mathrm{H}, \mathrm{m}), 1.07(9 \mathrm{H}, \mathrm{s}), 0.95(3 \mathrm{H}, \mathrm{t}, J=7.4 \mathrm{~Hz}), 0.91(3 \mathrm{H}, \mathrm{t}$, $J=7.4 \mathrm{~Hz}), 0.29(6 \mathrm{H}, \mathrm{s})$; FAB-MS $m / z 430(\mathrm{M}+\mathrm{H})^{+}$

8-t-Butyldimethylsilyloxy-3-(1-benzyl-1-cyano-2-phenyl)ethyl-6-methoxy-1-oxo-1H-2-benzopyran (20c)

By use of a procedure analogous to that described for the 
preparation of 20a, 20c was prepared from 18 and benzyl bromide ( $86 \%$ yield).

IR $(\mathrm{KBr}) \mathrm{cm}^{-1} 2240,1745,1600,1170,840 ; \mathrm{UV}$ $(\mathrm{MeOH}) \lambda_{\max } \mathrm{nm}(\varepsilon) 247(55,700), 325(6,500) ;{ }^{1} \mathrm{H}$ NMR $\left(\mathrm{CDCl}_{3}\right) \delta 7.23(10 \mathrm{H}, \mathrm{s}), 6.43(1 \mathrm{H}, \mathrm{d}, J=2.2 \mathrm{~Hz}), 6.19(1 \mathrm{H}$, d, $J=2.2 \mathrm{~Hz}), 6.06(1 \mathrm{H}, \mathrm{s}), 3.77(3 \mathrm{H}, \mathrm{s}), 3.49(2 \mathrm{H}, \mathrm{d}, J=$ $13.6 \mathrm{~Hz}), 3.20(2 \mathrm{H}, \mathrm{d}, J=13.6 \mathrm{~Hz}), 1.10(9 \mathrm{H}, \mathrm{s}), 0.32(6 \mathrm{H}$, $\mathrm{s})$; HR-FABMS $m / z$ calcd for $\mathrm{C}_{32} \mathrm{H}_{36} \mathrm{NO}_{4} \mathrm{Si}(\mathrm{M}+\mathrm{H})^{+}$ 526.2414 , found 526.2391 .

2-(8-Hydroxy-6-methoxy-1-oxo-1H-2-benzopyran-3-yl)2-methyl-propionic Acid (21a)

To a solution of $20 a(369 \mathrm{mg}, 0.99 \mathrm{mmol})$ in $\mathrm{AcOH}(4$ $\mathrm{ml})$ was diluted with conc. $\mathrm{HCl}(4 \mathrm{ml})$. After stirring at $70^{\circ} \mathrm{C}$ for 15 hours, the solution was added water $(15 \mathrm{ml})$ and stirred at room temperature for 3 hours. The precipitate was collected by filtration, washed with water and dried in vacuo to give the crude 21a. The crude 21a was decolorized with charcoal $(100 \mathrm{mg})$ in hot EtOH $(10 \mathrm{ml})$. Recrystallization from acetone-hexane (4:9) gave 21a (126 mg, 45\% yield).

IR (KBr) cm ${ }^{-1} 1725,1685,1170 ; \mathrm{UV}(\mathrm{MeOH}) \lambda_{\max } \mathrm{nm}$ (c) $244(54,100), 329$ (7,500); ${ }^{1} \mathrm{H}$ NMR (DMSO- $\left.d_{6}\right) \delta$ $10.87(1 \mathrm{H}, \mathrm{s}), 6.74(1 \mathrm{H}, \mathrm{s}), 6.71(1 \mathrm{H}, \mathrm{d}, J=2.2 \mathrm{~Hz}), 6.55$ $(1 \mathrm{H}, \mathrm{d}, J=2.2 \mathrm{~Hz}), 3.86(3 \mathrm{H}, \mathrm{s}), 1.45(6 \mathrm{H}, \mathrm{s})$; HR-FABMS $m / z$ calcd for $\mathrm{C}_{14} \mathrm{H}_{15} \mathrm{O}_{6}(\mathrm{M}+\mathrm{H})^{+}$279.0869, found 279.0872 .

2-(8-Hydroxy-6-methoxy-1-oxo-1H-2-benzopyran-3-yl)2-propyl-valeramide (21b)

To a solution of $20 \mathrm{~b}(346 \mathrm{mg}, 0.81 \mathrm{mmol})$ in $\mathrm{AcOH}(2$ $\mathrm{ml}$ ) was added sulfuric acid $(2 \mathrm{ml})$. After stirring at $70^{\circ} \mathrm{C}$ for 16 hours, the reaction mixture was diluted with water and extracted with EtOAc $(50 \mathrm{ml})$. The organic layer was washed with water and brine, dried over $\mathrm{Na}_{2} \mathrm{SO}_{4}$, and then concentarated. The residue was purified by silica gel chromatography to give $\mathbf{2 1 b}(210 \mathrm{mg}, 78 \%$ yield).

IR (KBr) cm ${ }^{-1} 1680$; UV (MeOH) $\lambda_{\max } \mathrm{nm}(\varepsilon) 245$ $(60,000), 330(8,200) ;{ }^{1} \mathrm{H} \mathrm{NMR}\left(\mathrm{CDCl}_{3}\right) \delta 10.97(1 \mathrm{H}, \mathrm{s})$, $6.50(1 \mathrm{H}, \mathrm{d}, J=2.2 \mathrm{~Hz}), 6.43(1 \mathrm{H}, \mathrm{s}), 6.39(1 \mathrm{H}, \mathrm{d}, J=2.2$ $\mathrm{Hz}), 5.73(1 \mathrm{H}$, br), 5.48 (1H, br), $3.87(3 \mathrm{H}, \mathrm{s}), 1.87 \sim 1.99$ $(4 \mathrm{H}, \mathrm{m}), 1.18 \sim 1.33(4 \mathrm{H}, \mathrm{m}), 0.97(6 \mathrm{H}, \mathrm{t}, J=7.3 \mathrm{~Hz})$; FAB$\mathrm{MS} m / z 334(\mathrm{M}+\mathrm{H})^{+}$

2-(8-Hydroxy-6-methoxy-1-oxo-1H-2-benzopyran-3-yl)2-phenylmethyl-3-phenyl-propionamide (21c)

By use of a procedure analogous to that described for the preparation of $\mathbf{2 0 b}, \mathbf{2 1 c}$ was prepared from $\mathbf{2 0 c}(85 \%$ yield).

IR $(\mathrm{KBr}) \mathrm{cm}^{-1} 1680 ; \mathrm{UV}(\mathrm{MeOH}) \lambda_{\max } \mathrm{nm}(\varepsilon) 247$
(53,000), $331(7,500)$; ${ }^{1} \mathrm{H} \mathrm{NMR}\left(\mathrm{CDCl}_{3}\right) \delta 10.96(1 \mathrm{H}, \mathrm{s})$, $7.14 \sim 7.26(10 \mathrm{H}, \mathrm{m}), 6.51(1 \mathrm{H}, \mathrm{d}, J=2.2 \mathrm{~Hz}), 6.25(1 \mathrm{H}, \mathrm{s})$, $6.23(1 \mathrm{H}, \mathrm{d}, J=2.2 \mathrm{~Hz}), 5.60(2 \mathrm{H}, \mathrm{s}), 3.84(3 \mathrm{H}, \mathrm{s}), 3.34$ $(2 \mathrm{H}, \mathrm{d}, J=14.0 \mathrm{~Hz}), 3.29(2 \mathrm{H}, \mathrm{d}, J=14.0 \mathrm{~Hz})$; HR-FABMS $m / z$ calcd for $\mathrm{C}_{26} \mathrm{H}_{24} \mathrm{NO}_{5}(\mathrm{M}+\mathrm{H})^{+}$430.1654, found 430.1634 .

2-(8-Hydroxy-6-methoxy-1-oxo- $1 H$-2-benzopyran-3-yl)propionic acid (2a, NM-3)

To a solution of $19 \mathrm{a}(14.27 \mathrm{~g}, 39.75 \mathrm{mmol})$ in $\mathrm{AcOH}$ $(120 \mathrm{ml})$ was diluted with conc. $\mathrm{HCl}(120 \mathrm{ml})$. After stirring at $80^{\circ} \mathrm{C}$ for 8 hours, the mixture was added water $(90 \mathrm{ml})$, and stirred at room temperature for 15 hours. The precipitate was collected by filtration, washed with water and dried in vacuo to give crude $2 \mathbf{a}$. The crude $\mathbf{2 a}$ was decolorized with charcoal $(1 \mathrm{~g})$ in hot EtOH $(10 \mathrm{ml})$. Recrystallization from acetone - hexane $(1: 5)$ gave $2 \mathbf{a}(8.40$ g, $80 \%$ yield).

IR (KBr) cm $\mathrm{cm}^{-1} 1720,1690,1240,1170$; UV (MeOH) $\lambda_{\text {max }}$ nm $(\varepsilon) 244(24,400), 330(7,900)$; ${ }^{1} \mathrm{H}$ NMR (DMSO$\left.d_{6}\right) \delta 12.87(1 \mathrm{H}, \mathrm{s}), 10.90(1 \mathrm{H}, \mathrm{s}), 6.68(1 \mathrm{H}, \mathrm{s}), 6.67(1 \mathrm{H}, \mathrm{d}$, $J=2.2 \mathrm{~Hz}), 6.56(1 \mathrm{H}, \mathrm{d}, J=2.2 \mathrm{~Hz}), 3.86(3 \mathrm{H}, \mathrm{s}), 3.70(1 \mathrm{H}$, q, $J=7.4 \mathrm{~Hz}), 1.39(3 \mathrm{H}, \mathrm{d}, J=7.4 \mathrm{~Hz})$. HR-FABMS $m / z$ calcd for $\mathrm{C}_{13} \mathrm{H}_{13} \mathrm{O}_{6}(\mathrm{M}+\mathrm{H})^{+} 265.0712$, found 265.0711 .

2-(8-Hydroxy-6-methoxy-1-oxo-1H-2-benzopyran-3-yl)butyric acid (2b)

By use of a procedure analogous to that described for the preparation of $2 \mathbf{a}, \mathbf{2 b}$ was prepared from $19 \mathbf{b}$ ( $84 \%$ yield).

IR (KBr) cm $\mathrm{cm}^{-1} 1715,1690,1165$; UV (MeOH) $\lambda_{\max } \mathrm{nm}$ (e) $245(47,200), 329(6,300) ;{ }^{1} \mathrm{H}$ NMR (DMSO-d $)_{6} \delta$ $10.90(1 \mathrm{H}, \mathrm{s}), 6.69(1 \mathrm{H}, \mathrm{s}), 6.67(1 \mathrm{H}, \mathrm{d}, J=2.2 \mathrm{~Hz}), 6.56$ $(1 \mathrm{H}, \mathrm{d}, J=2.2 \mathrm{~Hz}), 3.86(3 \mathrm{H}, \mathrm{s}), 3.48(1 \mathrm{H}, \mathrm{dd}, J=7.3$ and $8.1 \mathrm{~Hz}), 1.88 \sim 1.96(1 \mathrm{H}, \mathrm{m}), 1.77 \sim 1.86(1 \mathrm{H}, \mathrm{m}), 0.91(3 \mathrm{H}$, $t, J=7.3 \mathrm{~Hz}$ ). HR-FABMS $m / z$ calcd for $\mathrm{C}_{14} \mathrm{H}_{15} \mathrm{O}_{6}(\mathrm{M}+\mathrm{H})^{+}$ 279.0869 , found 279.0841 .

2-(8-Hydroxy-6-methoxy-1-oxo-1H-2-benzopyran-3-yl)3-phenyl-propionic acid (2c)

By use of a procedure analogous to that described for the preparation $2 \mathbf{a}, \mathbf{2 c}$ was prepared from $19 \mathrm{c}$ ( $80 \%$ yield).

IR (KBr) $\mathrm{cm}^{-1} 1685,1165$; UV (MeOH) $\lambda_{\max } \mathrm{nm}(\varepsilon)$ $246(51,900), 331$ (7,000); ${ }^{1} \mathrm{H}$ NMR (DMSO- $\left.d_{6}\right) \delta 10.86$ $(1 \mathrm{H}, \mathrm{s}), 7.12 \sim 7.27(5 \mathrm{H}, \mathrm{m}), 6.59(1 \mathrm{H}, \mathrm{d}, J=2.2 \mathrm{~Hz}), 6.58$ $(1 \mathrm{H}, \mathrm{s}), 6.54(1 \mathrm{H}, \mathrm{d}, J=2.2 \mathrm{~Hz}), 3.93(1 \mathrm{H}, \mathrm{dd}, J=6.6$ and $8.8 \mathrm{~Hz}), 3.83(3 \mathrm{H}, \mathrm{s}), 3.27(1 \mathrm{H}, \mathrm{dd}, J=6.6$ and $14.0 \mathrm{~Hz})$, $3.10(1 \mathrm{H}$, dd, $J=8.8$ and $14.0 \mathrm{~Hz})$. HR-FABMS $m / z$ calcd for $\mathrm{C}_{19} \mathrm{H}_{17} \mathrm{O}_{6}(\mathrm{M}+\mathrm{H})^{+} 341.1025$, found 341.1028 . 


\section{Acknowledgment}

We wish to thank Dr. Tsutomu Oikawa, The Tokyo Metropolitan Institute of Medical Science, for helpful advice on the anti-angiogenesis experiment.

\section{References}

1) Kumagai, H.; T. Masuda, M. Ohsono, S. Hattori, H. Naganawa, T. SaWa, M. Hamada, M. Ishizuka \& T. TAKEUCHI: Cytogenin, a novel antitumor substance. J. Antibiotics 43: 1505 1507, 1990

2) Hirano, S.; K. Wakazono, N. Agata, T. Mase, R. Yamamoto, M. Matsufuji, N. SaKata, H. Iguchi, $H$. TONE, M. IshizUKA \& T. TAKEUCHI: Effects of cytogenin, a novel anti-arthritic agent, on type II collagen-induced arthritis in DBA/1J mice and adjuvant arthritis in Lewis rat. Int. J. Tiss. Reac. 16: 155 162, 1994

3) Abe, C.; S. Hirano, K. Wakazono, T. Mase, R. Yamamoto, M. Matsufuji, N. Sakata, N. Agata, H. Iguchi, M. IsHIZUKA \& T. TAKEUCHI: Effects of cytogenin on spontaneous arthritis in MRL/1 mice and on pristane-induced arthritis (PIA) in $\mathrm{DBA} / 1 \mathrm{~J}$ mice. Int. J. Tiss. Reac. 17: 175 180, 1995

4) Oikawa, T.; M. Sakai, M. Inoue, M. Shimamura, H. Kuboki, H. Hirano, H. Kumagai, M. Ishizuka \& $T$. TAKEUCHI: Effects of cytogenin, a novel microbial product, on embryonic and tumor cell-induced angiogenic responses in vivo. Anticancer Res. 17: $1881 \sim 1886,1997$

5) Nakashima, T.; S. Hirano, N. Agata, H. Kumagai, K. Isshiki, T. Yoshioka, M. IsHIzUKa, K. MAEDA \& T. TAKEUCHI: Inhibition of angiogenesis by a new isocoumarin, NM-3. J. Antibiotics 52: 426 428, 1999 